\title{
PKM Konservasi Air Tanah di Kecamatan Mappakasunggu dan Manggarabombang Kabupaten Takalar
}

\section{Groundwater Conservation in Mappakasunggu and Manggarabombang, District Takalar}

\author{
${ }^{1}$ Muhammad Hamzah Syahruddin, ${ }^{1}$ Amiruddin, ${ }^{1}$ Halmar Halide, \\ ${ }^{1}$ Sakka, ${ }^{1}$ Makharani
}

${ }^{1}$ Departemen Geofisika FMIPA Universitas Hasanuddin, Makassar

Korespondensi: M.H. Syahruddin, hamzah@fmipa.unhas.ac.id

Naskah Diterima: 14 Agustus 2018. Disetujui: 09 Nopember 2019. Disetujui Publikasi: 28 Februari 2020

\begin{abstract}
Groundwater is water that is contained in layers of soil or rocks below the surface. Many damages are caused by excessive groundwater extraction. For example, one of the residents' wells in Tamaona Lengkese that had been closed because the water had turned to salt water after being used for 10 years. This phenomenon shows that there is sea water intrusion because the rate of groundwater exploitation is greater than the rate of recharge. Besides that, every year there is a drought in the dry season and flooding in the rainy season. Therefore, to avoid a prolonged water crisis, there must be efforts from the government and all levels of society to conserve groundwater. To overcome the various problems of the partners, the Unhas PPMU-PKM team conducted groundwater conservation counseling and training. Counseling is done to the community to understand the existence of ground water and how its conservation. While training was given to improve the skills of the community to conserve groundwater. The results of this education and training are that more than $80 \%$ participants have understood how the presence of ground water and its conservation and are able to conserve groundwater with infiltration holes and injection wells.
\end{abstract}

Keywords: Biopore, permeability, ground water, conservation.

\begin{abstract}
Abstrak. Air tanah adalah air yang terdapat dalam lapisan tanah atau bebatuan di bawah permukaan tanah. Banyak dampak kerusakan yang ditimbulkan akibat pengambilan air tanah yang berlebihan. Sebagai contoh, salah satu sumur warga di Tamaona Lengkese yang telah ditutup karena airnya sudah berubah menjadi air asin setelah digunakan 10 tahun. Fenomena ini menunjukkan adanya intrusi air laut karena laju pengambilan air tanah jauh lebih besar dibandingkan dengan laju pengimbuhan. Selain itu setiap tahun di daerah tersebut terjadi kekeringan pada musim kemarau dan banjir pada musim hujan. Oleh karena itu, harus ada upaya pemerintah dan lapisan masyarakat untuk melakukan konservasi air tanah untuk menghindari krisis air berkepanjangan. Untuk mengatasi berbagai persoalan mitra tersebut tim PPMU-PKM Unhas melakukan penyuluhan dan pelatihan konservasi air tanah. Penyuluhan dilakukan kepada masyarakat untuk memahami keberadaan air tanah dan bagaimana konservasinya. Sedangkan pelatihan diberikan untuk meningkatkan keterampilan masyarakat untuk melakukan konservasi air tanah. Hasil dari penyuluhan dan pelatihan ini adalah peserta telah memahami bagaimana keberadaan air tanah dan konservasinya diatas $80 \%$ dan mampu melakukan konservasi air tanah dengan lubang resapan dan sumur injeksi.
\end{abstract}

Kata kunci: Biopori, permeabilitas, air tanah, konservasi. 


\section{Pendahuluan}

Air tanah adalah air yang terdapat dalam lapisan tanah atau bebatuan di bawah permukaan tanah. Air tanah merupakan sumber daya alam yang sangat vital bagi makhluk hidup. Air tanah tersebut tersimpan dalam lapisan yang disebut akuifer. Jadi akuifer adalah pembawa air tanah dan tempat penyimpanan air tanah di bawah permukaan. Akuifer tersebut dapat dijumpai pada dataran pantai, daerah kaki gunung, lembah antar pegunungan, dataran aluvial dan daerah topografi karst (Notodarmojo, 2005).

Banyak dampak kerusakan yang ditimbulkan akibat pengambilan air tanah yang berlebihan (Tresnadi, 2007). Pengambilan air tanah dalam akuifer yang terus menerus dan tidak terkendali dapat mengakibatkan terjadinya gangguan terhadap lingkungan. Kerusakan lingkungan yang bisa terjadi karena eksploitasi air tanah yang berlangsung lama dan tak terkendali adalah penurunan muka air tanah, penurunan muka tanah (subsidence), dan perubahan kualitas air tanah. Sebagai contoh, salah satu sumur warga di Tamaona Lengkese yang telah ditutup karena airnya sudah berubah menjadi air asin setelah digunakan 10 tahun. Fenomena ini menunjukkan bahwa laju pengambilan air tanah jauh lebih besar dibandingkan dengan laju pengimbuhan. Indikasi tersebut memperlihatkan bahwa pemulihan air tanah tidak bisa dilestarikan melalui pengimbuhan secara alamiah. Oleh karena itu, harus ada upaya pengimbuhan air tanah secara buatan.

Kegiatan manusia dengan membangun inprastruktur perumahan, jalan, gedung-gedung dan fasilitas lain tanpa memperhitungkan lahan terbuka hijau mengakibatkan daerah resapan air hujan semakin sempit. Permukaan tanah semakin padat sehingga pori-pori tanah semakin kecil (Rosyidah \& Wirosoedarmo, 2013). Ini menyebabkan air larian (run off) semakin besar. Penyebab lain adalah pembuangan sampah di aliran badan air sehingga air tidak bisa mengalir dengan lancar yang pada akhirnya mengakibatkan banjir. Persoalan lain yang banyak dihadapi masyarakat adalah tumpukan sampah organik dan sampah anorganik. Hasil Survey EHRA Kabupaten Takalar mengemukakan bahwa sebanyak 48,9\% sampah rumah tangga masih berserakan. Volume sampah di Kecamatan Manggarabombang adalah $110 \mathrm{~m}^{3} /$ hari dan volume sampah di Kecamatan Mappakasungguh adalah $45 \mathrm{~m}^{3}$ / hari (http://ppsp.nawasis.info/).

Pertambahan jumlah penduduk berakibat pada pertambahan permukiman. Permukiman di wilayah perkotaan telah padat, termasuk banyak berdiri gedunggedung perhotelan yang membutuhkan suplai air berlimpah. Kebutuhan air, terutama air tanah sulit dihindari. Permukiman tidak dapat dihentikan, maka sasaran berikutnya adalah lahan yang ada di luar perkotaan. Perluasan lahan permukiman yang seakan-akan sulit terkendali berdampak pada menyempitnya lahan peresapan air hujan. Berbagai dampak telah muncul, seperti kekeringan di wilayah perkotaan karena banyak sumur semakin dalam permukaan airnya. Dibutuhkan segera ada tindakan untuk konservasi air tanah di wilayah pemukiman dan sekitarnya untuk menghindari krisis air berkepanjangan (Purwantara, 2015).

Sumur-sumur yang telah berubah kualitasnya tidak dapat digunakan untuk mencuci, mandi apalagi untuk memasak karena terasa airnya payau, berwarna dan keruh dan berbau. Tetapi setelah sumur resapan dialiri air hujan maka terjadi perubahan yang siknifikan. Sumur- sumur resapan yang payau, berwarna dan keruh setelah dialiri air hujan, air sumur menjadi tawar, tidak berwarna dan jernih. Sumur-sumur yang sebelumnya berbau, setelah dialiri air hujan baunya hilang. Hasil pengujian air setelah sumur resapan dilalui air hujan adalah kualitas air sumur menjadi lebih baik (Azis, dkk., 2006).

Beberapa tahun terakhir telah dikembangkan teknologi Lubang Resapan 
Biopori (LRB) untuk mengatasi sampah organik banjir (Brata \& Nelistya, 2008). Kedalamannya tidak melebihi muka air tanah, yaitu sekitar $100 \mathrm{~cm}$ dari permukaan tanah. LRB dapat meningkatkan kemampuan tanah dalam meresapkan air. Air tersebut meresap melalui biopori yang menembus permukaan dinding LRB ke dalam tanah di sekitar lubang. Dengan demikian, akan menambah cadangan air dalam tanah serta menghindari terjadinya aliran air di permukaan tanah. LRB merupakan teknologi tepat guna dan ramah lingkungan untuk mempercepat peresapan air hujan dan mengatasi masalah sampah organik. Lubang resapan biopori dinamakan teknologi biopori karena memanfaatkan aktivitas fauna tanah atau akar tanaman (bio) yang membentuk lubang-lubang terowongan kecil (pore) di dalam tanah. Peran organisme di dalam tanah itulah yang sering dilupakan dalam merancang konsep penanganan banjir.

Melestarikan air tanah dengan teknologi tepat guna (TTG) yaitu sumur resapan (LRB), dan sumur injeksi. Sumur injeksi dapat dilakukan dengan beberapa cara (Sunarto, 2007). Sumur resapan injeksi dan pemanfaatan berbeda tempat dikenal dengan singkatan suisuitan. Sumur resapan injeksi dan sumur pemanfaatan menyatu disingkat sumintan. Sumur resapan injeksi dan sumur pemanfaatan berdekatan disingkat suratan. Lubang resapan injeksi suisuitan, sumintan, suratan disingkat (SRI3S). Lubang resapan biopori berbentuk parit persegi panjang di sekitar rumah (Syahruddin, 2018). Lubang resapan biopori persegi panjang disingkat (LRBP).

Berdasarkan uraian di atas maka upaya yang dilakukan dalam pengabdian ini adalah bagaimana meningkatkan dan memaksimalkan pengimbuhan air hujan ke dalam tanah di daerah Manggarabombang dan Mappakasunggu sehingga tidak terjadi intrusi air asin ke dalam reservoir. Sebagai contoh di Tamaona Lengkese, beberapa sumur masyarakat menjadi asin karena pengambilan dan pengimbuhan tidak seimbang. Pendekatan sedini mungkin untuk menghindari intrusi air asin ke dalam akuifer di daerah Manggarabombang dan Mappakasungguh adalah membuat sumur resapan untuk pengimbuhan. Metoda yang dilakukan dalam pengabdian ini adalah penyuluhan dan pelatihan pembuatan sumur resapan biopori, pembutan lubang silindris yang mencapai akuifer dangkal di daerah Manggarabombang dan Mappakasunggu. Diharapkan dengan adanya lubang resapan ini yang mencapai akuifer dangkal di Daerah Manggarabombang dan Mappakasungguh dapat menjaga keseimbagan antara pengambilan air tanah dengan pengimbuhan.

Pengabdian ini bertujuan untuk melakukan konservasi air tanah dengan metoda sumur resapan. Sumur resapan gravitasi bertujuan untuk memaksimalkan penyimpanan air dalam tanah pada musim hujan. Pelestarian sumber daya air tanah, perbaikan kualitas lingkungan dan membudayakan kesadaran lingkungan. Membantu menanggulangi kekurangan air bersih. Menjaga kesetimbangan air di dalam tanah dalam sistem akuifer. Mengurangi limpasan permukaan (run off) dan erosi tanah.

Sebenarnya masyarakat kita sejak dulu banyak memanfaatkan pekarangan rumah untuk mengolah sampah organik dengan membuat lubang di sekitar rumahnya. Sampah organik ini dibuang atau diletakkan di dalam lubang untuk menjadi tanah kembali setelah diurai oleh organisma dalam tanah. Meskipun tujuan awalnya adalah membuang sampah tetapi tanpa mereka sadari bahwa lubang yang dibuat tersebut berfungsi sebagai lubang resapan air pada musim hujan yang sangat potensial. Jadi kebiasaan masyarakat membuat lubang sampah organik perlu kita sosialisasikan dan galakkan kembali untuk melestarikan teknologi tradisionil. Namun seiring dengan waktu jumlah penduduk yang makin banyak sehingga pekarangan rumah semakin sempit untuk membuat lubang 
sampah organik bahkan tidak ada lagi pekarangan karena bangunan perumahan dan bangunan lainnya yang semakin padat.

Tujuan penyuluhan dan pelatihan ini adalah agar masyarakat mempunyai pemahaman yang komprehensip pentingnya pengeloalan lingkungan khususnya kesadaran masyarakat berpartisipasi dalam pengelolaan sumber daya air. Sinergi antara Tim PPMU-PKM dari UNHAS dan mitra dalam mengedukasi masyarakat, akan meningkatkan keterampilan dan kemampuan masyarakat dalam bidang pelestarian air tanah. Manfaat kegiatan ini adalah meningkatnya pemahaman keberadaan air tanah dan kesadaran masyarakat akan pentingnya pengolahan sumber daya air untuk kelestarian air tanah dan menambah ketrampilan peserta melestarikan air tanah dengan teknologi tepat guna (TTG) yaitu lubang resapan biopori (LRB) berbentuk silindris, sumur resapan injeksi (SRI3S), dan lubang resapan biopori parit persegipanjang (LRBP) di sekitar rumah.

\section{Metode Pelaksanaan}

Tempat dan Waktu. Kegiatan pengabdian kepada masyarakat ini dilaksanakan di dua tempat yang berbeda. Tempat pertama adalah Desa pa'batangan Kecamatan Mappakasunggu. Pelaksanaan penyuluhan dan pelatihan dilaksanakan aula SMPN Mapsu. Kegiatan dilaksankan pada 21-22 Juli 2018 di Patani Desa Pakbatangan. Tempa kedua adalah Desa Lengkese Kecamatan Manggarabombang. Penyuluhan dan pelatihan dilaksanakan di aula Kantor Kepala Desa Lengkese. Kegiatan dilaksanakan pada tanggal 4-5 Agustus 2018 di Mangadu Desa Lengkese. Peta tempat kegiatan pelaksanaan penyuluhan dan pelatihan konservasi air tanah dapat dilihat pada Gambar 1 .

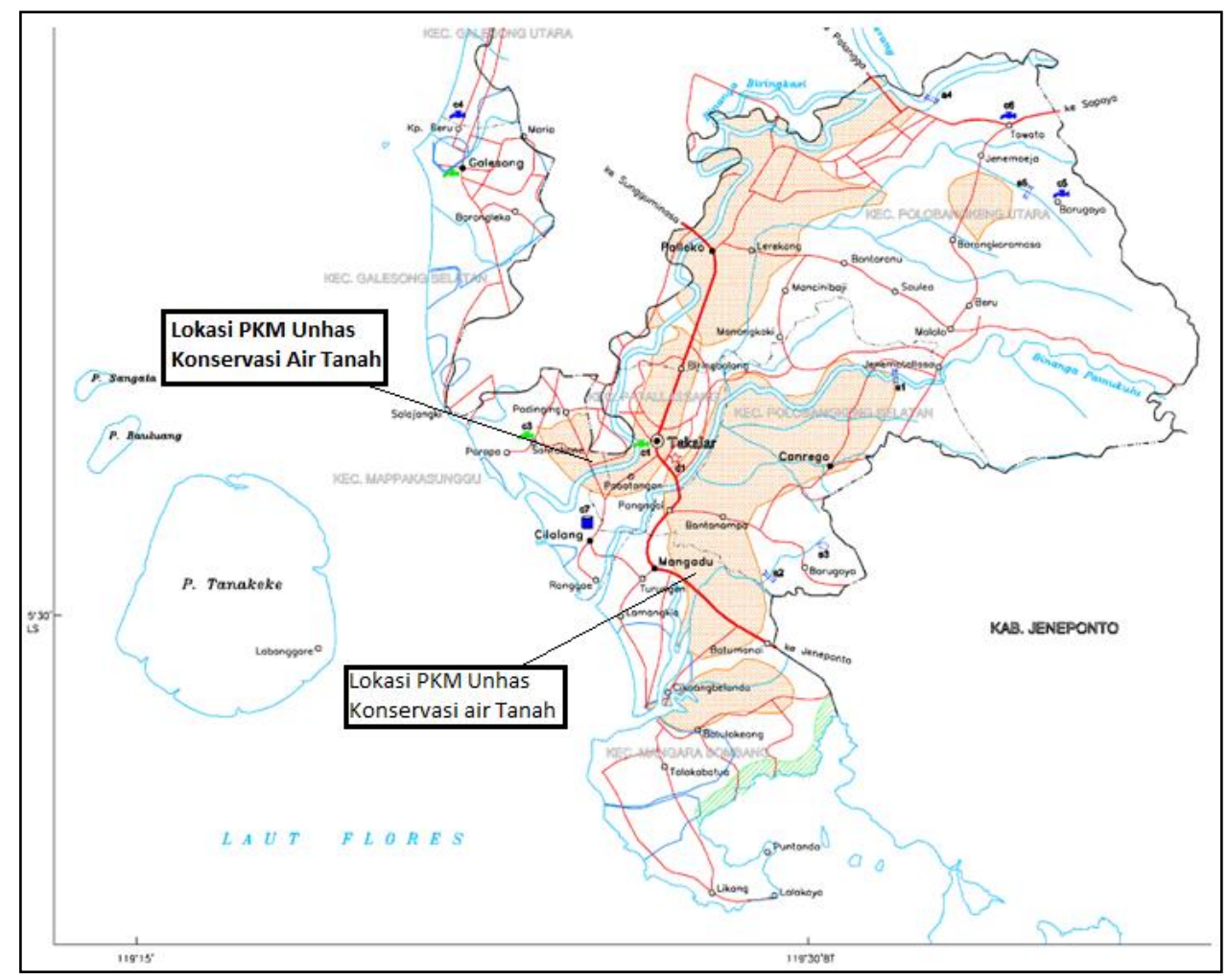

Gambar 1. Peta lokasi PKM Unhas penyuluhan dan pelatihan konservasi air tanah

Khalayak Sasaran. Khalayak sasaran sebagai mitra dalam kegiatan ini adalah masyarakat Desa Pakbatanagan dan masyarakat Desa Lengkese Kecamatan Mappakasunggu dan Kecamatan Manggarabombang Kabupaten Takalar Sulawesi 
Selatan. Khalayak sasaran adalah aparat Desa, masyarakat petani dan guru di kedua desa tersebut. Jumlah peserta di Desa Pakbatangan 30 orang dan jumlah peserta di Desa Lengkese juga 30 orang. Jadi jumlah keseluruhan peserta adalah 60 orang. Diharapkan dari 60 orang peserta ini dapat menjadi contoh kepada masyarakat lainnya bagaimana melakukan konservasi air tanah. Tim PKM dari Unhas menyiapkan materi penyuluhan dan meyiapkan peralatan pelatihan konservasi air tanah. Sedangkan Kepala Desa dan timnya menyiapkan tempat dan peserta dalam kegiatan ini. Peserta penyuluhan dan pelatihan ini diundang oleh kepala Desa Pakbatangan dan Kepala Desa Lengkese.

Metode Pengabdian. Kegiatan ini dilakukan dengan dua tahap yaitu penyuluhan dan pelatihan. Pada hari pertama, penyuluhan dilakukan kepada kepada peserta untuk memberikan pemahaman bagaimana siklus air dalam tanah dan bagaimana melakukan konservasi air tanah. Penyuluhan ini juga bertujuan untuk memberikan informasi dan menambah wawasan peserta tentang bahaya yang ditimbulkan oleh akibat kerusakan daerah resapan air tanah. Selain itu diperkenalkan peralatan konservasi air tanah dan bagaimana menggunakan. Selanjutnya pada hari kedua, dilaksakan pelatihan konservasi air tanah. Dalam pelatihan ini, peserta melakukan praktek pembuatan lubang resapan biopori (LRB), membuat simulasi sumur resapan injeksi suisuitan, sumintan, suratan (SRI3S) dari sumur masyarakat yang ada dan membuat lubang resapan biopori berbentuk persegi panjang (LRBP).

Indikator Keberhasilan. Indikator keberhasilan kegiatan pengabdian masyarakat ini dalam bentuk penyuluhan adalah meningkatnya pemahaman peserta tentang siklus air tanah dan bagaimana konservasinya. Pelatihan konservasi air tanah dapat meningkatkan keterampilan peserta dalam pembuatan LRB, pembuatan SRI3S dan pembuatan LRBP. Target luaran diukur melalui pre-test dan post test dengan kriteria sebagai berikut:

Nilai 20-40 = pemahaman dan keterampilan kurang

Nilai 41-60 = pemahaman dan keterampilan cukup

Nilai 61-100 = pemahaman dan keterampilan baik

Indikator keberhasilan lain yang digunakan adalah testimoni yang secara lisan dari peserta setelah pelatihan dilaksanakan.

Metode Evaluasi. Metode evaluasi dilakukan dalam dua tahap. Tahap pertama dilakukan di pertengahan kegiatan berupa dialog dengan khalayak sasaran. Tahap kedua dilakukan di akhir kegiatan dengan membandingkan hasil pre-test dan post test (Rifa'i, dkk., 2017, 2018; Kudsiah, dkk., 2018). Kegiatan dinyatakan berhasil apabila indikator keberhasilan dapat tercapai dengan nilai 61-100.

\section{Hasil dan Pembahasan}

\section{A. Penyuluhan Konservasi Air Tanah}

Acara penyuluhan dan pelatihan konservasi air tanah di Desa Pakbatangan dibuka oleh Kepala Desa Pakbatangan, Muhammad Yasin, ST. Dalam sambutannya Kepala Desa menyatakan bahwa konservasi air tanah di desanya sangat penting karena kualitas air tanah terus turun. Terbukti banyak sumur masyarakat yang sudah payau dan tidak layak di konsumsi. Padahal mayoritas masyarakat mengandalkan air tanah untuk memenuhi kebutuhannya. Oleh karena itu Kepala Desa Pakbatangan sangat antusias mengikuti penyuluhan dan pelatihan yang dilaksanakan oleh tim PPMU-PKM dari Unhas dan berjanji akan memprogramkan pelestarian air tanah ini dari dana desa tahun depan. Foto peserta pelatihan dapat dilihat pada Gambar 2 .

Penyuluhan dan pelatihan konservasi air tanah di Desa Lengkese dibuka oleh Sekretaris Desa Lengkese, Syaharuddin, S.Sos. Setelah pembukaan penyuluhan 


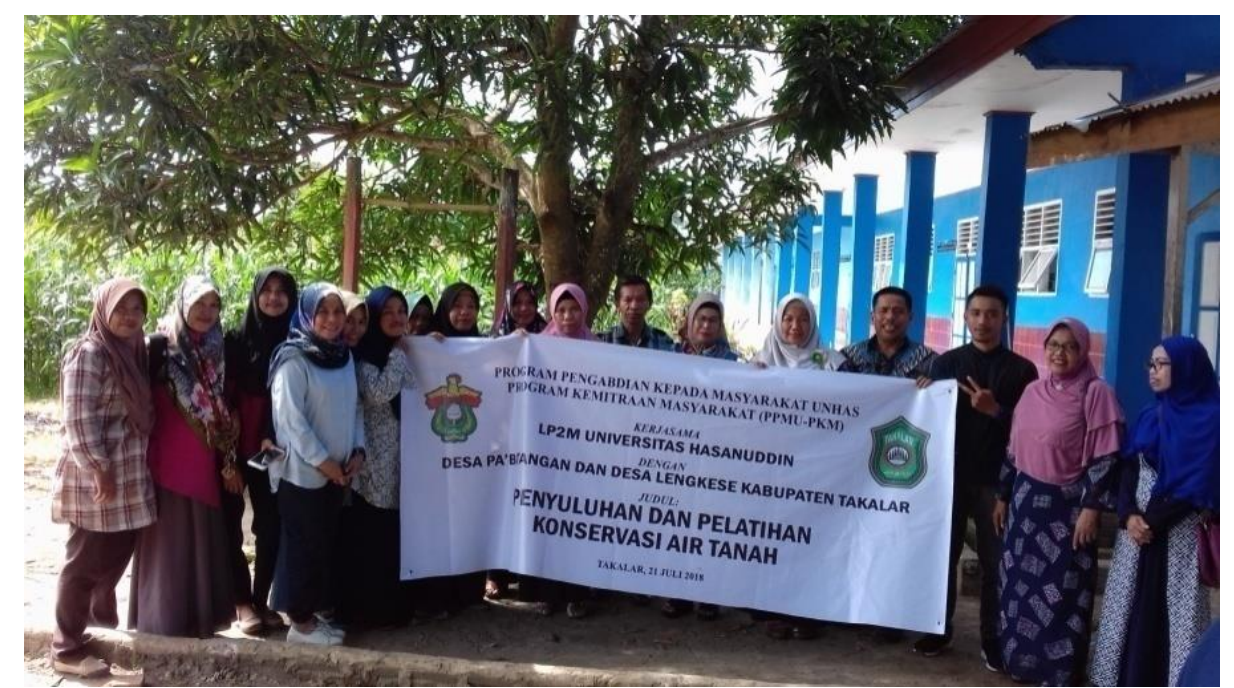

Gambar 2. Foto peserta penyuluhan dan pelatihan konservasi air tanah di Desa Pakbatagan Kecamatan Mappakasunggu

dan pelatihan di Desa Lengkese, Sekertaris Desa Lengkese memaparkan program kegiatan yang telah dilaksanakan dan yang akan dilaksanakan di desa lengkese dari dana desa. Program yang telah banyak dilaksanakan adalah infrastruktur desa seperti jalan-jalan desa dan prasarana lainnya. Salah satu program yang akan dilaksanakan adalah pembuatan embung di desa Lengkese untuk pelestarian air tanah. Pembuatan embung ini diharapkan dapat berfungsi sebagai daerah resapan dan dapat menyediakan air pada musim kemarau. Diharapkan pula dari embung tersebut dapat mencegah intrusi air laut ke dalam tanah di Desa Lengkese. Foto peserta pelatihan Desa Lengkese dapat dilihat pada Gambar 3.

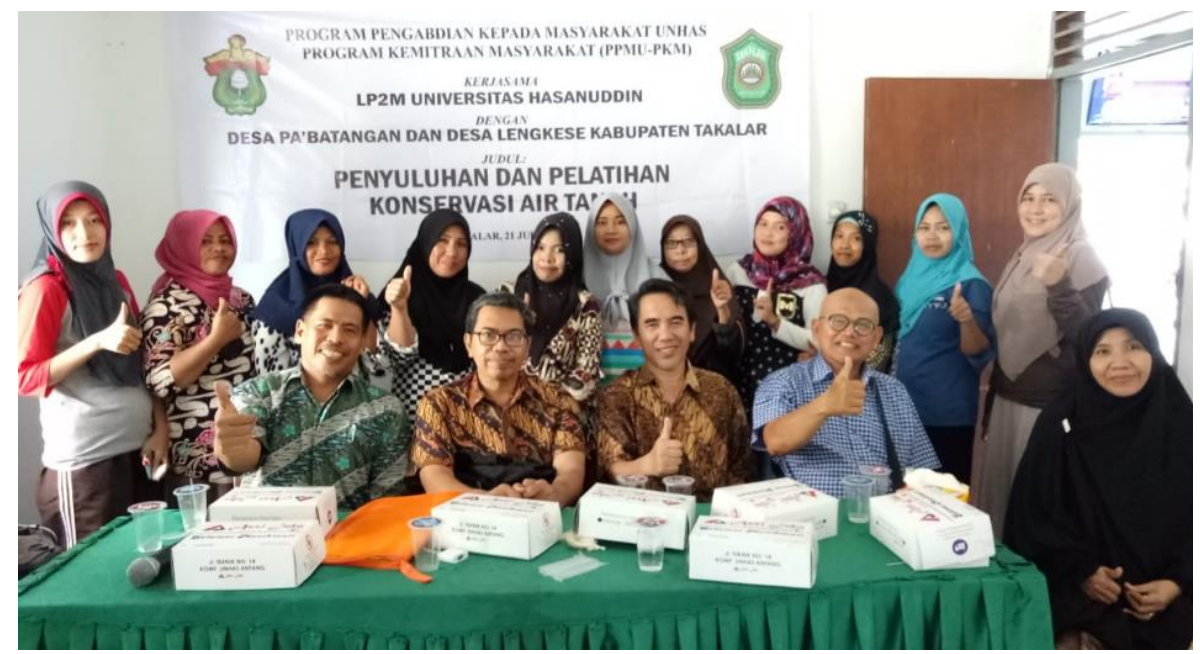

Gambar 3. Foto peserta penyuluhan dan pelatihan konservasi air tanah di Desa Lengkese Kecamatan Manggarabombang

Kegiatan penyuluhan pemahaman teoritik keberadaan air tanah disampaikan oleh Prof. Halmar Halide. Peserta antusias menerima materi dari Prof. Halmar Halide, yang memulai pemaparannya mengutip ayat suci Al'Quran \{Az-Zumar: 21\}. Apakah kamu tidak memperhatikan, bahwa sesungguhnya Allah menurunkan air dari langit, maka diaturnya menjadi sumber-sumber air di bumi kemudian ditumbuhkan-Nya dengan air itu tanam-tanaman yang bermacam-macam warnanya. Foto penyampaian materi penyuluhan dari prof. Halmar dapat dilihat pada Gambar 4. 


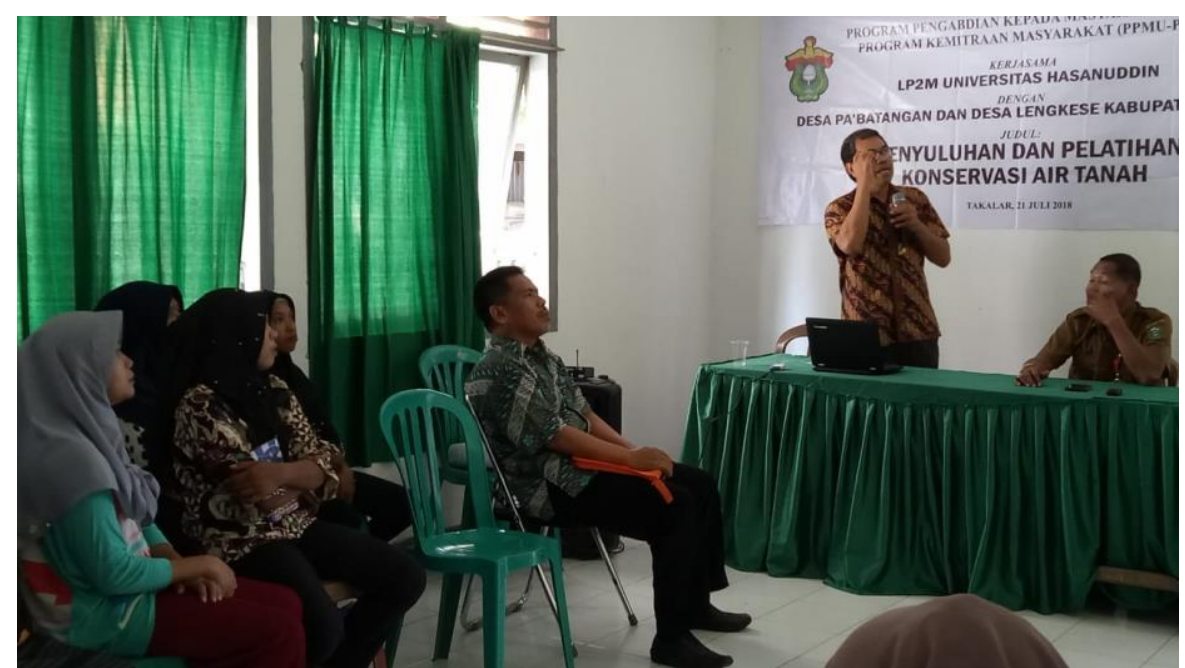

Gambar 4. Foto penyuluhan keberadaan air tanah dan pelestariannya

Keberadaan air di laut di darat dan di udara mengikuti siklus hidrologi. Siklus air atau siklus hidrologi adalah sirkulasi air yang tidak pernah berhenti dari atmosfer ke bumi dan kembali ke atmosfer melalui kondensasi, presipitasi, evaporasi dan transpirasi. Siklus hidrologi memegang peran penting bagi kelangsungan hidup organisme bumi. Melalui siklus ini, ketersediaan air di daratan bumi di dalam tanah sebagai air tanah dapat tetap terjaga. Teraturnya suhu lingkungan, cuaca, hujan, dan keseimbangan ekosistem bumi dapat tercipta semuanya karena proses siklus hidrologi ini. Secara ringkas siklus hidrologi dapat dilihat pada Gambar 5.

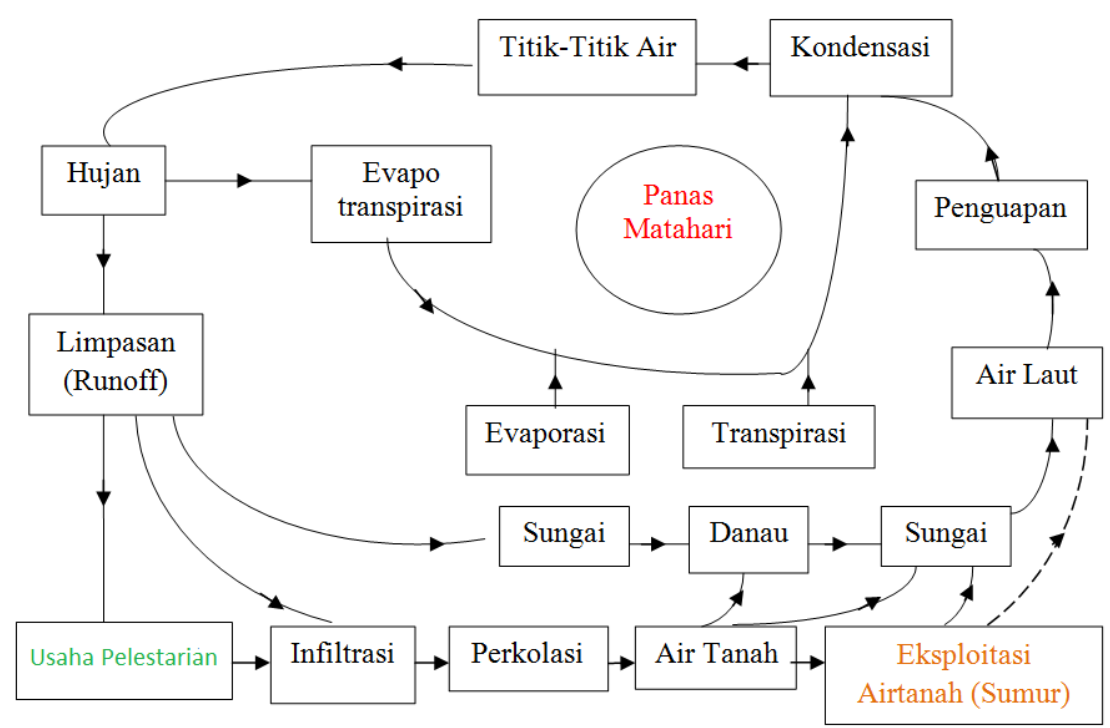

Gambar 5. Siklus hidrologi, eksploitasi dan pelestariannya

Selajutnya di akhir pemaparannya prof. Halmar menyampaikan bahwa dalam peraturan pemerintah Nomor 82 Tahun 2001 pengendalian pencemaran air wajib bagi setiap orang, dan pemerintah. Barang siapa memasukkan barang sesuatu ke dalam sumur, pompa, mata air atau ke dalam perlengkapan air minum untuk umum atau untuk dipakai oleh atau bersama-sama, dengan orang lain, padahal ia tahu bahwa karena perbuatan itu air akan menjadi berbahaya bagi nyawa atau kesehatan orang, diancam dengan pidana penjara paling lama lima belas tahun. 
Selanjutnya Dr. Muhammad Hamzah menjelaskan mengapa kita perlu melestarikan air tanah. Seperti yang terlihat pada Gambar 5 usaha pelestarian air tanah perlu dilakukan jika ada eksploitasi air tanah. Usaha pelestarian air tanah dilakukan untuk menjaga keseimbangan antara pengambilan dan pengisian kembali air tanah. Jika keseimbangan ini terjadi maka tidak akan terjadi kekeringan, subsidence, intrusi air laut yang menyebabkan sumur menjadi asin. Usaha-usaha yang dapat dilakukan dalam pelestarian air tanah adalah membuat sumur atau lubang resapan. Ada beberapa bentuk sumur resapan antara lain sumur resapan dan sumur pemanfaatan berbeda tempat (suisuitan), sumur injeksi dan sumur pemanfaatan menyatu (sumintan), sumur resapan dan sumur pemanfaatan (suratan) (Soenarto, 2017). Sedangkan pelestarian air tanah dapat pula dilakukan dengan Lubang Resapan Biopori Silindris (Barata, 2008) dan Lubang resapan Biopori Kubus persegi panjang (Syahruddin, 2018).

Pelestarian air tanah di daerah pemukiman dapat dilakukan dengan cara membuat lubang resapan berbentuk silindris atau lubang resapan berbentuk kubus. Lubang-lubang tersebut dikenal dengan lubang resapan biopori (LRB). Lubang resapan adalah lubang penampungan air sementara (sesaat) untuk selanjutnya meresapkannya kembali ke pori-pori tanah. Pori-pori tanah adalah ruang antara butiran padat tanah. Biopori adalah pori-pori tanah yang terbentuk karena aktivitas hewan dan tumbuhan. Biopori memperbesar daya tampung tanah terhadap air hujan, mengurangi genangan air, yang selanjutnya mengurangi limpahan air hujan turun ke sungai. Kedalaman LRB berada di atas kedalaman muka air tanah. Untuk mengaktifkan LRB maka lubang diisi dengan sampah organik untuk memicu terbentuknya biopori akibat berbagai akitifitas organisma di dalam tanah.

\section{B. Pelatihan Konservasi Air Tanah}

Setelah penyuluhan penyampaian materi pelestarian air tanah maka dilanjutkan kegiatan pelatihan pembuatan LRB, simulasi SRI3S dan pembuatan LRBP. Sebelum dilakukan pembuatan LRB dan LRBP terlebih dahulu diberikan kursus singkat penggunaan alat pemboran LRB dan alat pembuatan LRBP. Sedangkan simulasi SRI3S dilakukan di salah satu rumah warga yang mempunyai sumur. Caranya adalah air permukaan yang diinjeksikan ke dalam akuifer SRI3S terjaga kualitasnya. Praktek pembuatan LRB dan LRBP dapat dilihat pada Gambar 6.

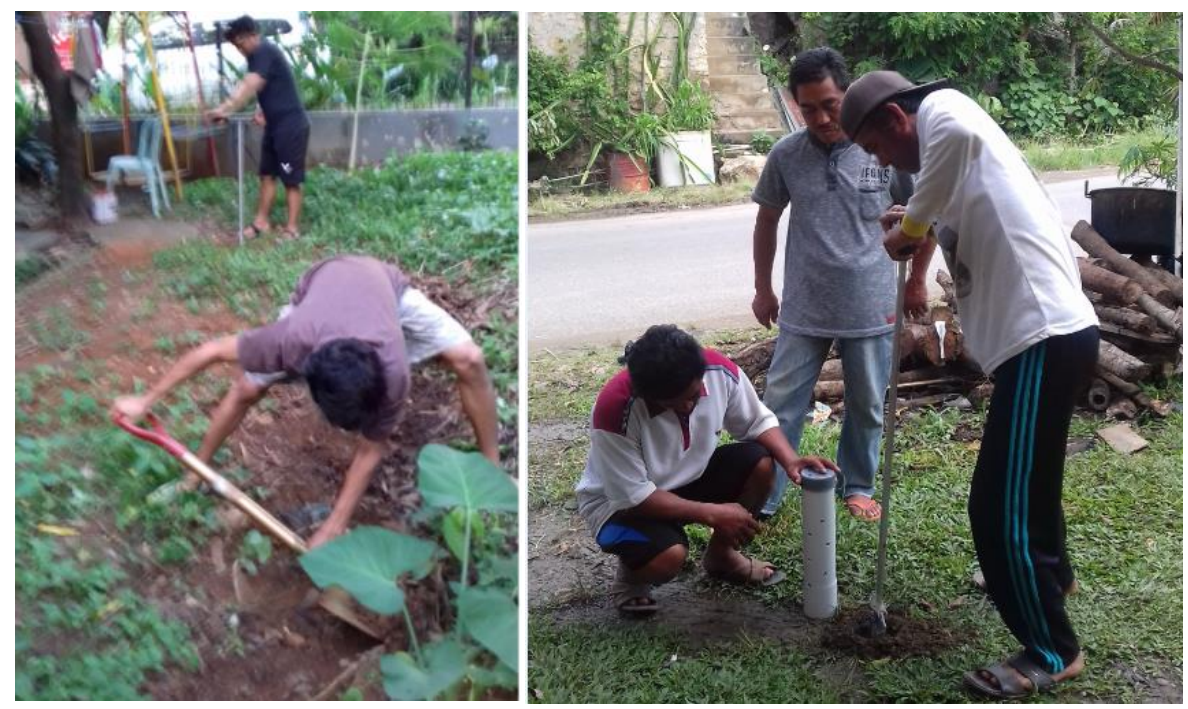

Gambar 6. Foto Pelatihan pembuatan LRB dan LRBP 
Kegiatan pelatihan dilakukan di tempat terbuka yaitu pekarangan rumah Bapak Kepala Desa Pakbatangan. Pekarangan rumah Kepala Desa berukuran $10 \mathrm{~m}$ x $20 \mathrm{~m}\left(200 \mathrm{~m}^{2}\right)$. Menurut Rahmasari, dkk., (2015), untuk lubang yang bebentuk silindris maka ukuran atau jumlah LRB yang diperlukan pada luasan tanah tertentu dapat ditentukan. Penentuan jumlah LRB silindris pada luasan tanah tertentu bergantung pada permeabilitas tanah dan intensitas curah hujan. Hasil pengujian permeabilitas tanah di pekarangan Kepala Desa Pakbatangan dapat dilihat pada Tabel 1.

Tabel 1. Hasil Pengujian Permeabilitas Tanah Pekarangan

Kepala Desa Pakbatangan

\begin{tabular}{lrrrrr}
\hline Parameter & LSR1 & LSR2 & LSR3 & LSR4 & Rerata \\
\hline Kedalaman $(\mathrm{cm})$ & 30 & 70 & 100 & - & 40 \\
Volume $\left(\mathrm{cm}^{\wedge} 3\right)$ & 1500 & 1500 & 1500 & - & 900 \\
Waktu (det) & 2040 & 4200 & 8400 & - & 2928 \\
debit & 0,735294 & 0,357143 & 0,178571 & - & 0,307377 \\
Permeabiltas $(\mathrm{cm} / \mathrm{s})$ & 0,001084 & 0,000526 & 0,000263 & - & 0,000375 \\
\hline
\end{tabular}

LSR: Lubang silindris resapan

Hasil pengujian menunjukkan bahwa lubang silindris resapan1 (LSR1) mempunyai permeabilitas $0,00108 \mathrm{~cm} / \mathrm{s}$. Permeabilitas LSR2 adalah 0,000526 $\mathrm{cm} / \mathrm{s}$. Permeabilitas LSR3 adalah $0,00263 \mathrm{~cm} / \mathrm{s}$. Permeabilitas tanah rata-rata di pekarangan Kepala Desa Pakbatangan adalah 0,000375 cm/s. Permeabilitas tanah di pekarangan rumah Kepala Desa Pakbatnagan menunjukkan bahwa permeabilitas semakin kecil bila lubang semakin dalam. Trend permeabilitas tanah di pekarangan rumah Kepala Desa Pakbatangan dapat dilihat pada Gambar 7.

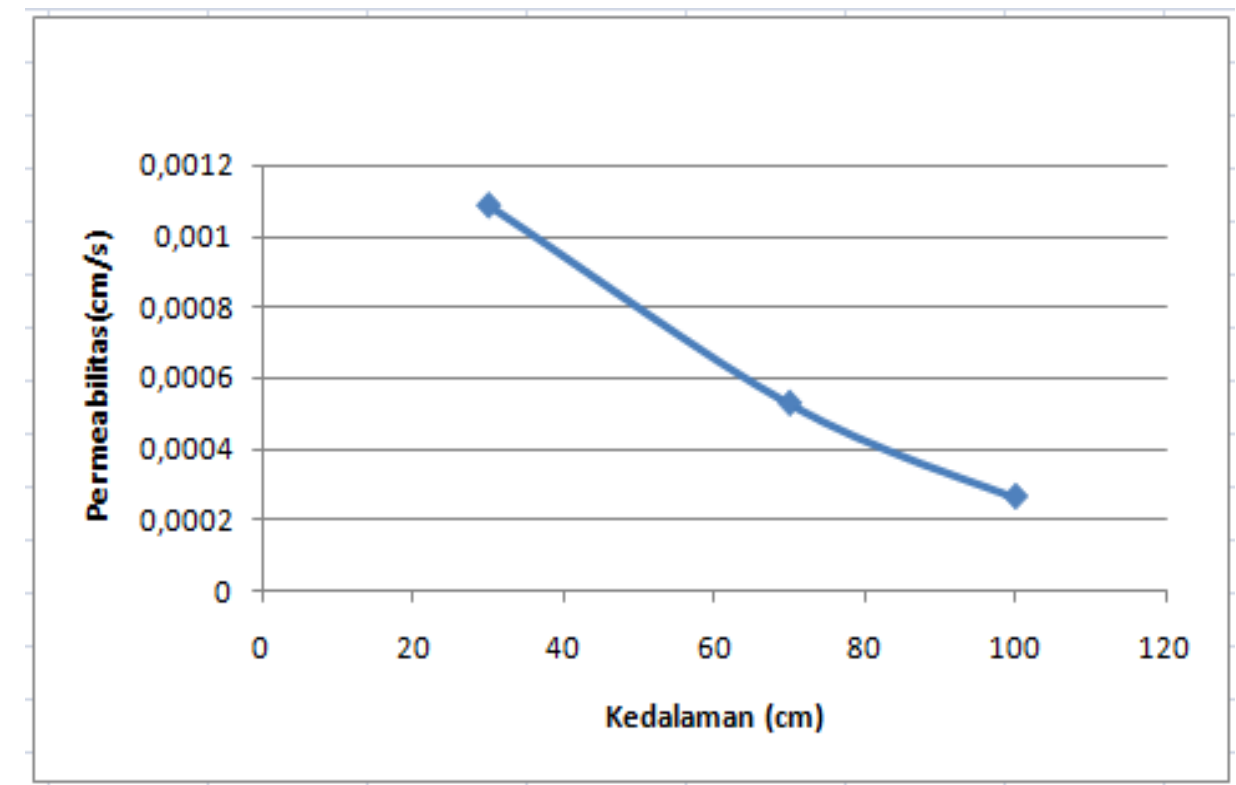

Gambar 7 Hasil pengujian permeabilitas tanah di pekarangan Kepala Desa Pakbatangan

Desain LRB dapat berbentuk silindris atau berbentuk kubus bergantung dari ketersediaan lahan yang ada. Jika ketersediaan lahan yang cukup maka LRB dapat berbentuk kubus. Tetapi jika lahan sempit biasanya dibuat lubang berbentuk silindris berdiameter $10 \mathrm{~cm}$ pada kedalaman tidak lebih dari $100 \mathrm{~cm}$ dari permukaan tanah. LRB silindris ini cocok diterapkan pada pemukiman yang padat 
penduduk seperti di pusat kota. Sedangkan LRB kubus cocok diterapkan di pinggiran kota atau desa-desa yang jarang penduduk.

Praktek pengujian permeabilitas tanah dilakukan pula di Desa Lengkese. Pengujian permeabilitas dilakukan untuk lubang yang bebentuk silindris berdiameter $10 \mathrm{~cm}$. Jumlah lubang pengujian sebanyak lima buah yaitu LRS1 sampai LSR5. Dari hasil pengujian diperoleh permeabilitas LSR1 adalah 0,00374. Permeabilitas LSR2 adalah 0,002902. Permeabilitas LSR3 adalah 0,00283. Permeabilitas LSR4 adalah 0,006966. Permeabilitas LSR5 adalah 0,005805. Permeabilitas tanah di daerah lengkese rata-rata adalah $0,00445 \mathrm{~cm} / \mathrm{s}$. Hasil pengujian permeabilitas di beberapa titik di pekarangan rumah warga Tamaona Lengkese menunjukkan bahwa permeabilitas merata sampai kedalaman $80 \mathrm{~cm}$. Pengujian permeabilitas Tamaona Lengkese secara langsung dilapangan dapat dilihat pada Tabel 2 .

Tabel 2. Hasil Uji Permeabilitas In-Situ Tamaona Lengkese

\begin{tabular}{lrrrrrr}
\hline Parameter & LSR1 & LSR2 & LSR3 & LSR4 & LSR5 & \multicolumn{1}{c}{ Rerata } \\
\hline Kedalaman $(\mathrm{cm})$ & 15 & 30 & 40 & 80 & 80 & 49 \\
Volume $\left(\mathrm{cm}^{\wedge} 3\right)$ & 500 & 1000 & 1500 & 1000 & 1000 & 1000 \\
Waktu (det) & 420 & 900 & 780 & 300 & 360 & 552 \\
debit & 1,190476 & 1,111111 & 1,923077 & 3,333333 & 2,777778 & 1,811594 \\
Permeabiltas $(\mathrm{cm} / \mathrm{s})$ & 0,00374 & 0,002902 & 0,002834 & 0,006966 & 0,005805 & 0,004449 \\
\hline
\end{tabular}

LSR: Lubang silindris resapan

Sebagai contoh perhitungan jumlah LRB silindris yang diperlukan untuk luasan tanah $100 \mathrm{~m}^{2}$. Dari Tabel 2 diketahui laju resapan air rata-rata adalah 1000 $\mathrm{cm}^{3} / 552$ det. Jika di konversi ke dalam liter per hari maka kemampuan tanah menyerap air adalah 156,5 liter/hari. Jika curah hujan 0,02 m/hari dengan luasan tanah $100 \mathrm{~m}^{2}$ maka diperoleh volume air hujan $2 \mathrm{~m}^{3} /$ hari atau sama dengan 2000 liter/hari. Jadi jumlah LRB silidris yang diperlukan adalah 2000/156,5 sama dengan 12,77 .

Demikian pula LRBP dapat dihitung volumenya untuk meresapkan semua air hujan yang turun di permukaan tanah dengan luas tertentu. Tujuan utama LRBP adalah dapat menampung sampah organik yang berukuran besar seperti batang dan tangkai pohon. Oleh karena itu untuk dapat menampung sampah berukuran besar maka lubang resapan berbentuk kubus persegipanjang dapat menggunakan ukuran panjang tiga meter, lebar 0,5 meter dan kedalaman 0,5 meter. Dengan ukuran LRB kubus tersebut dapat pula menampung air hujan 0,75 kubik sesaat yang selanjutnya akan meresap ke dalam tanah. Manfaat LRBP adalah mengurangi air larian di permukaan, menghasilkan pupuk kandang, menyuburkan tanah, mengurangi tumpukan sampah, dan melestarikan air tanah.

\section{Keberhasilan Kegiatan Penyuluhan}

Indikator keberhasilan kegiatan pengabdian masyarakat ini dalam bentuk penyuluhan adalah meningkatnya pemahaman peserta tentang bagaimana keberadaan air tanah dan bagaimana konservasinya. Untuk mengetahui keberhasilan penyuluhan keberadaan air tanah dan konservasinya maka dilakukan pre-test dan post-test. Hasil pre-test dan post-test menunjukkan bahwa sebelum pelatihan di bawah 30\% dan setelah diberikan penyuluhan keberadaan air tanah dan koservasinya pemahan peserta meningkat diatas $80 \%$. Hasil pre-test dan posttest peserta penyuluhan dapat dilihat pada Gambar 8 . 
Pre-test

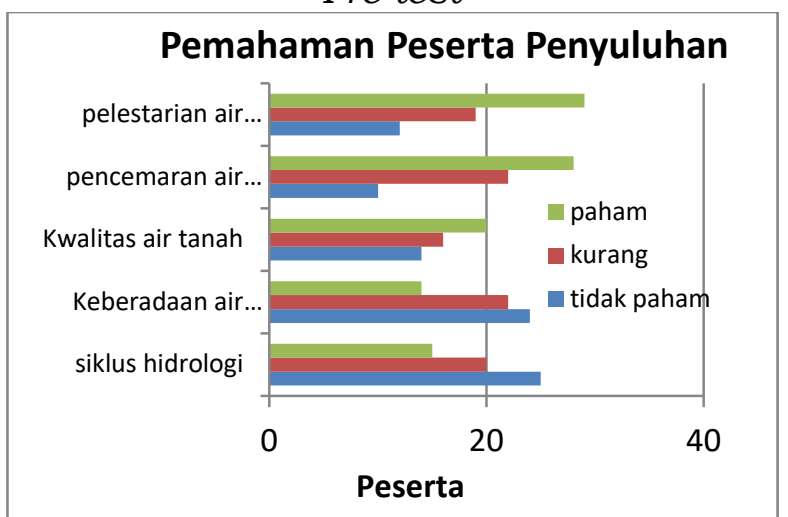

Post-test

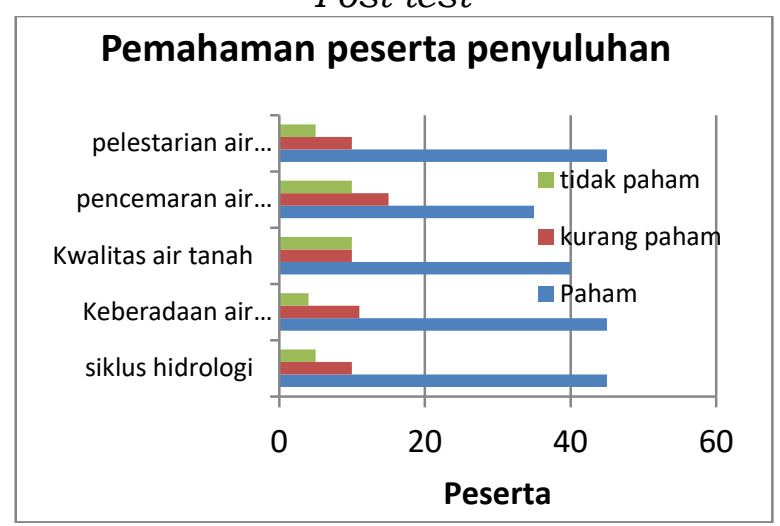

Gambar 8. Hasil pre-test dan post-tes pemahaman peserta penyuluhan

\section{Keberhasilan Kegiatan Pelatihan Konservasi Air Tanah}

Pelatihan konservasi air tanah dapat meningkatkan keterampilan peserta dalam pembuatan LRB, pembuatan SRI3S dan pembuatan LRBP. Peningkatan keberhasilan juga diukur melalui pre-test dan post-test. Hasil pre-test dan post-test menunjukkan bahwa sebelum pelatihan hanya di bawah 30\% mengalami peningkatan keterampilan peserta untuk konservasi air tanah di atas $80 \%$. Hasil pre-test dan post-test peserta pelatihan dapat dilihat pada Gambar 9.

Pre-test

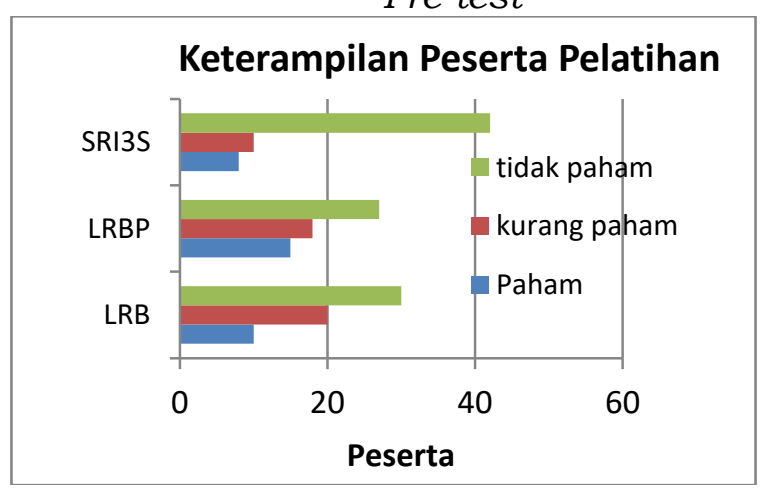

Post-test

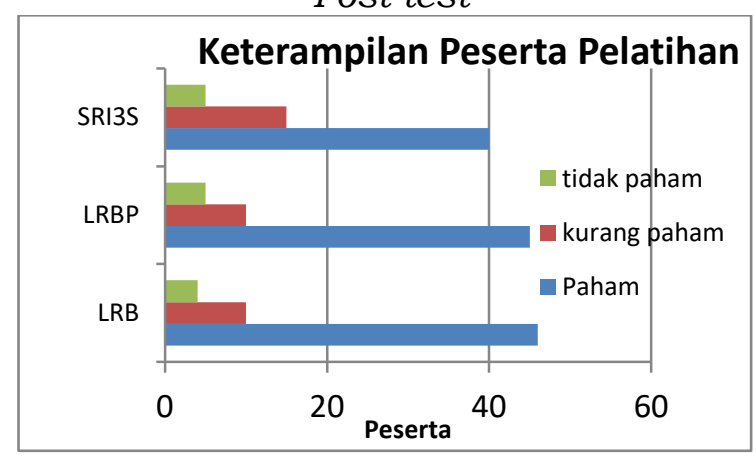

Gambar 9. Hasil pre-test dan post-test pemahaman peserta penyuluhan

\section{Kesimpulan}

Peserta telah memahami keberadaan air tanah dan konservasinya diatas $80 \%$ dan mampu melakukan konservasi air tanah dengan lubang resapan dan sumur injeksi. Wujud keberhasilan pelatihan ini adalah adanya semangat dan antusias peserta pelatihan dalam melestarikan air tanah. Peserta pelatihan akan mengusulkan pengadaan alat dan bahan untuk pelestarian air tanah menggunakan dana desa.

\section{Ucapan Terima Kasih}

Terima kasih disampaikan kepada LPPM Unhas yang telah memberikan dana dalam melakukan pengabdian kepada masyarakat di Desa Pa'batangan dan Desa Lengkese Kabupaten Takalar. Terima kasih disampaikan pula kepada Kepala Desa Pakbatangan dan Lengkese sebagai mitra yang menyiapakan tempat dan peserta dalam penyuluhan dan pelatihan konservasi air tanah. Terima kasih kepada semua pihak yang membantu baik langsung mapupun tidak langsung sehingga pengabdian ini dapat dilaksanakan. 


\section{Referensi}

Azis, A., Yusuf, H., \& Faisal Z. (2006). Konservasi Airtanah Melalui Pembuatan Sumur Resapan Air Hujan Di Kelurahan Maradekaya Kota Makassar, Journal intek, 3(2), 87-90.

Brata, K.R., \& Nelistya, N. (2008). Lubang Resapan Biopori. Depok, Penebar Swadaya, Jakarta.

Kudsiah, H., Tresnati, J., Ali , S.A., \& Rifa'I, M.A. (2018). IbM Kelompok Usaha Bandeng Segar Tanpa Duri di Kabupaten Pangkep Sulawesi Selatan. Panrita Abdi Jurnal, 2(1), 55-63.

Notodarmojo, S. (2005). Pencemaran Tanah dan Air Tanah, Penerbit ITB Bandung,

Purwantara, S. (2015). Dampak Pengembangan Permukiman Terhadap Air Tanah Di Wilayah Yogyakarta Dan Sekitarnya, Jurnal Geodukasi, 4(1), 31-40.

Rahmasari, A.F., Surupin., \& Sudarno. (2015). Pengaruh Peresapan Air Hujan Menggunakan Lubang Resapan Biopori (LRB), Jurnal Wahana Teknik Sipil, 20(1), 11-15.

Rifa'i, M.A., Kudsiah, H., \& Muzdalifah. (2017). Alih teknologi produksi benih anemon laut secara aseksual. Jurnal Panrita Abdi, 1(1), 33-39.

Rifa'i, M.A., Syahdan, M., Muzdalifah, \& Kudsiah, H. (2018). Pengembangan Usaha Produk Intelektual Kampus: Anemon Laut Ornamen. Jurnal Panrita Abdi, 2(1), 40-47.

Rosyidah, E. \& Wirosoedarmo, R. (2013). Pengaruh Sifat Fisik Tanah Pada Konduktivitas Hidrolik Jenuh di 5 Penggunaan Lahan, Jurnal Agritech UGM, 33(3) 340-345.

Sunarto, B. (2007). Teknik Sumur Injeksi untuk Pengendalian Banjir dan Keperluan Lain Serta Berbagai Teknik Ekivalen Lainnya, Journal JSDA, 3(4), 49-61.

Syahruddin, M.H. (2018). Groundwater Conservation with Hole Infiltration of Biopore Cube, IOP Conf. Series: Earth and Environmental Science (279), 01-07

Tresnadi, H. (2007). Dampak Kerusakan yang Ditimbulkan Akibat Pengambilan Air tanah yang Berlebihan. Jurnal Alami, $12: 76-81$.

(2016). Dokumen Perencanaan Sanitasi Kabupaten Takalar http://ppsp. nawasis.info/dokumen/perencanaan/sanitasi/pokja/newssk/kab.takalar/BAB\%2 OII.pdf. Diakses 14 Agustus 2018.

Penulis:

Muhammad Hamzah Syahruddin, Departemen Geofisika, Fakultas Matematika dan Ilmu Pengetahuan Alam Universitas Hasanuddin, Makassar, email: hamzah@fmipa.unhas.ac.id

Amiruddin, Departemen Geofisika, Fakultas Matematika dan Ilmu Pengetahuan Alam Universitas Hasanuddin, Makassar, email: amir_mipa@yahoo.com

Halmar Halide, Departemen Geofisika, Fakultas Matematika dan Ilmu Pengetahuan Alam Universitas Hasanuddin, Makassar, email: halmarh@yahoo.com

Sakka, Departemen Geofisika, Fakultas Matematika dan Ilmu Pengetahuan Alam Universitas

Hasanuddin, Makassar, email: sakka.fisika@yahoo.com

Makhrani, Departemen Geofisika, Fakultas Matematika dan Ilmu Pengetahuan Alam Universitas

Hasanuddin, Makassar, email: $\underline{\text { rani_anshar@yahoo.co.id }}$

Bagaimana men-sitasi artikel ini:

Syahruddin, M.H., Amiruddin, Halide, H., Sakka, \& Makhrani. (2020). PKM Konservasi Air Tanah di Kecamatan Mappakasunggu dan Manggarabombang Kabupaten Takalar. Jurnal Panrita Abdi, 4(2), 172 $-183$. 